\title{
THE PERCEIVED SCHOOL CLIMATE IN CROATIAN ELEMENTARY SCHOOLS WITH POOR, AVERAGE AND GOOD SCHOOL'S LEARNING ENVIRONMENT ${ }^{*}$
}

\author{
Josip Burušic ${ }^{* *}$
}

Received: 13. 7. 2018

Original scientific paper

Accepted: 4. 3. 2019

UDC 37.018.2:37.06

DOI https://doi.org/10.30924/mjcmi.24.si.1

\begin{abstract}
The cross-sectional research design was used to investigate differences in teachers' perception of school climate in schools with poor, average and good school's learning environment, and to explore to what degree is possible to explain six school climate dimensions by school's learning environment, some teacher's characteristics and teaching practice experience. Participants in the study were 785 teachers from 44 primary schools in northern part of Croatia, 121 males and 579 females. Participants rated school climate in school where they teach and in addition provided information about various school's learning environment. Schools which teachers perceived as having good school's learning environment clearly differ in the level
\end{abstract}

\section{INTRODUCTION}

Ever since the seminal study by Coleman et al. (1966), it is possible to identify two general trends in the field of school effectiveness research. The first trend is primarily based on the identification and cataloguing of numerous determinants of school of school climate quality - school climate is significantly better in schools with better school's learning environment. The performed hierarchical regression analyses, demonstrated in addition, how school's learning environment and characteristics of teachers and teaching practice (e.g. gender, age, work experience and education level) are powerful predictors of (positive) school climate. In this paper, we provide possible explanation and stress importance on school climate as an essential concept in school effectiveness concerns and activities.

Keywords: school climate, school's learning environment, elementary school, school effectiveness

effectiveness, with the aim of exploring the strength of a relation between schools' or students' achievement, as most used indicators of school effectiveness and various possible determinants of achievement. The second trend is represented by numerous programs and initiative for school improvement, where primary concerns are related

\footnotetext{
${ }^{*}$ This research was supported by the Ministry of Science and Education of Republic of Croatia through Scientific of Excellence Centres and is a part of activities of Croatian Centre for School Effectiveness and Management research. Special thanks to Maja Ribar and Marija Šakić Velić for their help in preparation of the manuscript.

** Ivo Pilar Institute of Social Sciences, Croatian Center of Scientific Excellence for School Effectiveness and Management, Marulicev trg 19, 10000 Zagreb, Croatia. Email: Josip.Burusic@pilar.hr, Phone: (+3851) 48 86 832, Fax: (+3851) 4828296 .
} 
to desired student-level outcomes, teacher or school-level outcomes, as well as the outcomes on the level of entire educational system (Townsend, 2007).

Traditional studies have tried to identify the determinants of school effectiveness primarily among various structural characteristics of schools, such as physical, socioenvironmental and financial conditions in which they work, while the majority of contemporary studies are primarily focused on consideration of processes within schools, such as teaching styles, teacher behaviors and interactions. One of the reasons for this shift of focus are the outcomes of certain review studies, such as the Hanushek (1986) study, which have concluded that the relationship between structural characteristics of schools, primarily material and financial resources, and school achievement as an indicator of school effectiveness, is modest. However, some authors dispute Hanushek's (1986) findings (e. g. Hedges, Laine \& Greenwald, 1994) and claim that the positive correlation between school's material resources and school outcomes is not challenged. Namely, sufficient evidence exists that schools which have more material resources available are more successful, but this evidence did not prevent the strengthening of focus of educational research on the role of processes within schools.

An important group of studies that have been focused on processes within schools are those on the role of school climate in improving school effectiveness (Berkowitz, Moore, Astor, \& Benbenishty, 2017). In the beginning, these studies were based on the expectation that better material conditions in schools, and more favorable sociodemographic characteristics of parents and social composition of student population, result in a greater demand of a school upon teachers, better quality of school administration, and consequently more effective teaching styles and methods. This approach did not consider the direct, but only the indirect effects of a more favorable school climate. As Berkowitz at all. (2017) stated, better material conditions generally increase the differences in dominant patterns of behavior of students, teachers and parents, which has indirect effects on effectiveness. Today, it is noticeable that all processes within a school are significant determinants of school climate, and school climate affects the effectiveness of teaching and learning within a school, and is related to achievement of students, teachers and schools (Dronkers \& Robert, 2003).

\section{LITERATURE REVIEW}

Jonathan Cohen of American National School Climate Council stated in aninfluential paper that school climate represents "patterns of people's experiences of school life and reflects norms, goals, values, interpersonal relationships, teaching and learning practices, and organizational structures" (Cohen, McCabe, Michelli, \& Pickeral, 2009, p. 180). In the existing literature, different terms are used for the concept of school climate. Yonezawa, Jones, Mehan, \& McClure (2008) state that the concept of school climate is also termed "the ecology of the school," "a safe and healthy school setting," "classroom participation structures," a "caring school environment" or the "culture of the school." These authors also assert that the concept of "personalization" is used in contemporary studies, which includes the need that schools approach each student individually, creating a school environment focused on satisfying the needs and wishes of each individual student. Halpin and Croft (1963), the pioneers of school climate research, think that the meaning of school climate corresponds to the meaning 
of "personality" in the case of an individual, with school climate being an indicator of "personality of school", since it encompasses collective perception of teachers of school behavior, and also affects the attitudes and behaviors of all the people in the school. In Croatian literature, Domović (2003, p. 143) defines school climate, as a relatively stable quality of school setting that affects the behavior of its members and is based on a common perception of behavior in the school, and is under the influence of formal organization, non-formal organization, personality of members and school management".

In contemporary educational literature, numerous review studies on different aspects of school climate can be found (e.g., Anderson, 1982; Benbenisty \& Astor, 2005; Cohen, McCabe, Michelli, \& Pickeral, 2009; Cohen \& Geier, 2010; Wang, \& Degol, 2016). These studies have an emphasis on the importance of school climate for understanding the effectiveness of schools and teachers in common, as well as recognition that school climate is an important concept, on which attempts of school improvement are based. Numerous empirical studies on the determinants of school climate also exist, as well as on the immediate and deferred effects of (poor) school climate on certain school outcomes. Thapa, Cohen, Guffey, \& Higgins-D'Alessandro (2013, p. 3) summarize the outcomes of studies stating that ,there seems to be an abundant literature on school climate from different parts of the world that documents a positive school climate: (a) having a powerful influence on the motivation to learn; (b) mitigating the negative impact of the socioeconomic context on academic success; (c) contributing to less aggression, violence, less harassment; (d) acting as a protective factor for the learning and positive life development of young people.“
If placed in the theoretical model of school effectiveness (Creemers \& Kyriakides, 2006), the construct of school climate would present a "school-level" factor, which basically reflects the quality of school processes, i. e. a collection of processes, perceptions, beliefs, common norms, and psychosocial conditions of teaching and teacher's work - in short, a collection of positive and supportive or negative and aversive factors within school that strengthen or suppress the effects of other factors on school effectiveness. Johnson and Stevens (2006, p. 2) state that "school climate can either be seen as a construct representing the involvement of everyone in a school or as something that is primarily a function of the teachers or of the students". In the case of school effectiveness model, school climate would present global involvement of all the actors.

Thapa et al. (2013, p. 2) claim that the global construct of school climate is comprised of five dimensions which should be considered, namely "(a) Safety (e.g., rules and norms, physical safety, socialemotional safety), (b) Relationships (e.g., respect for diversity, school connectedness/ engagement, social support, leadership, and students' race/ethnicity and their perceptions of school climate), (c) Teaching and Learning (e.g., social, emotional, ethical, and civic learning; service learning; support for academic learning; support for professional relationships; teachers' and students' perceptions of school climate), (d) Institutional Environment (e.g., physical surrounding, resources, supplies), and (e) the School Improvement Process".

Besides the theoretical definition of school climate, an important issue that has been (scarcely) examined in previous studies is the differences in school climate depending on different school characteristics, 
such as differences between more or less good functioning schools, which are in the focus of the present study. Several studies (e.g. Buening, 2014; Johnson and Stevens, 2006) have particularly examined this issue, but the possibility of generalization of findings is limited, for several reasons. The primary reason is different theoretical conceptualizations of school climate, resulting in different approaches to measurement. This problem was implicitly recognized in the early period of school climate studies by Anderson (1982), who considered (from the organizational theory point of view) that the definition of school climate is a great challenge for researchers, since numerous definitions and models exist, and the prominent practice is to approach the definition of the concept implicitly. As Thapa et al. (2013) state, this practice is present in large national research communities such as the USA, and it is even more pronounced in attempts to compare the outcomes from different educational systems, as well as in comparisons of educational systems according to their level and quality of school climate.

Bearing these conceptual and methodological challenges in mind, an important question that has not been adequately answered is to what extent school climate contributes to the achievement of students, teachers and schools that have different teaching, learning and working internal conditions. Johnson and Stevens (2006) have shown that the importance of school climate is greater in schools with better contextual conditions, such as schools in financially and socioeconomically more advanced surroundings. Cheema and Kitsantas (2014) state that the relationship between socioeconomic status (SES) and school achievement is weaker in schools with more positive school climate in comparison with schools with less positive school climate. Buening (2014) has shown that differences in school climate exist between private and public schools, favoring private schools, which produces differences in school achievement as well. Bryk and Schneider (2002) concluded that, in schools with better school climate, students of lower SES especially benefit from better school climate, attaining better school achievement than expected, based solely on their socioeconomic background. Van Houtte (2005) states that a basic cause of differences in school achievement is attributed to school climate.

However, as stated in a review paper by Berkowitz et al. (2016), despite empirical evidence and counterevidence, the expectations regarding the consequences of school climate for school effectiveness of schools with various characteristics are not clear. The reasons for this are differences in conceptualizations, measures, and proposed mechanisms through which positive school climate can contribute to the explanation of school achievement. One of the reasons lies also in numerous determinants of school climate and complexity of school climate as an organizational characteristic.

To summarize, numerous factors within a school shape a good or poor "learning environment" and should produce differences in school climate as well. It can be expected that school climate is better in schools with better organizational functioning, where learning environment is a crucial component, but this expectation is not sufficiently empirically confirmed in the existing literature.

\section{OBJECTIVE OF THE STUDY}

The general of this paper is to examine the relationship between school's learning environment and school climate, and 
to test differences in school climate between schools with poor, average and good school's learning environment. The outcomes of the present study can enrich the existing body of knowledge by providing empirically based evidence, which could improve the explanation and understanding of the role of school climate.

\section{METHOD}

\subsection{Participants}

Participants in the study were 785 teachers from 44 primary schools in northern part of Croatia, who participated in the program of research activities, conducted by the Centre of Scientific Excellence in School Effectiveness and School Management. In the total sample, 121 were males $(17.3 \%)$, 579 females $(83.7 \%)$, and 85 participants have not answered the question on their gender. The age range of participants was from 26 to 66 years, with the average age of 43.64 years $(S D=9.76)$. Participants had from zero to 43 years of work experience, with the average of 16.21 years $(S D=10.54)$. More than half of the participants $(475 ; 67.5 \%)$ had a university degree or higher level or education, while the remaining participants finished the teacher training college degree, or bachelor's degree equivalent.

\subsection{Constructs and measures}

Perceived School Climate. School climate was operationalized modified Organizational Climate Questionnaire for High Schools (Proroković \& Slišković, 2008), comprised of 63 items answered on a 4-point Likert type scale (1 - 'Seldom'; 4 - 'Almost Always'). Proroković and Slišović (2008) constructed the questionnaire, following theoretical and methodological idea of two previous questionnaires, namely Organizational Climate Description Questionnaire (Hoy \& Clover, 1986) and Organizational Climate Description Questionnaire (Kottkamp, Mulhern, \& Hoy, 1987). Conceptually, the instrument assesses various aspects of school climate related to the relationships among teachers, the relations of teachers towards work and students, and the relationship of principals towards teachers and school in general (Proroković \& Slišković, 2008). In this study, we used the instrument by Proroković and Slišković (2008) in the conceptually original form, with changes related to items content formulation, where we adopted official educational nomenclature appropriate for elementary schools (e.g. changing term "professor" to "teacher" etc.).

Principal axis factor analysis with Varimax rotation yielded a six-factor solution, with Scree-test as criterion for determining the number of factors. Some items from the full form of the questionnaire were excluded due to low communalities, low saturations with the obtained factors, and cross-loadings on several factors, as to obtain a simple and interpretable factor structure. The retained six factors explained $48.2 \%$ of total variance, with first factor explaining $14.14 \%$, second $14.14 \%$, third $5.64 \%$, fourth $5.55 \%$, fifth $5.03 \%$, and sixth $3.69 \%$ of variance. After analyzing the saturations, the first factor was named Interpersonal Relations at Work, the second Principal's Management Style, the third Relation towards Work and Students, the fourth Control, the fifth Interpersonal Relations outside Work, and sixth Work Overload. In computing scores for all factors, negative items were recoded in the way that higher scores reflect a more positive school climate. The reliabilities of the obtained school climate dimensions were $.92, .94, .81, .81, .78$, and 
.76 for Interpersonal Relations at Work, Principal's Management Style, Relation towards Work and Students, Control, Interpersonal Relations outside Work, and Work Overload, respectively.

Quality of School Learning Environment. Assessment of quality of school learning environment is conceptually derived from educational effectiveness models (e.g. Scheerens, 1989), where a list of internal school's work conditions and process-indicators of school functioning was created, encompassing the entire spectrum of internal conditions, which reflect school's learning environment. A total of 22 items related to learning environment were selected and teachers were asked to rate, on a five-point Likert type scale, to what extent each of these conditions was satisfactory in their school (1 - completely unsatisfactory; 5 completely satisfactory). This inventory of school learning environment conditions was analyzed by using the principal axis factor analysis with Varimax rotation. Three interpretable underlying factors of work conditions were obtained. One item ("Possibilities to sanction teachers who do not meet the expected standards") was removed from the analysis due to saturations for two factors. The retained three factors explained 54.12\% of total variance, with the first factor explaining $26.26 \%$, the second $14.69 \%$, and the third $13.17 \%$ of variance. Considering the content of items and conceptualization of school effectiveness model, the first factor was labelled Work Conditions at the Level of School, the second Relations between Students, and the third Relations Among Teachers. Cronbach alpha coefficient of internal reliability was .92 for the first factor, and .85 for the second and the third factor.

Teacher's Characteristics and Teaching Experiences. Some important and teaching characteristics were collected, such as teacher gender, number of years of teaching experience, and education level (lower and higher teacher education).

\subsection{Procedure}

The data was collected in groups, completely anonymously, as a part of research activities of the Croatian Center of Scientific Excellence in School Effectiveness and School Management. After obtaining participants' consent for participation in the study, the participants were asked to complete a questionnaire. The completion of the questionnaire lasted on average half an hour. After the questionnaires were completed, the teachers were thanked for their participation and the aims of the study were explained to them in detail.

\section{RESULTS}

To address the objective of this study, firstly the results exploring the role of school's learning environment and characteristics of teachers and teaching in the prediction of dimensions of school climate are presented. For this purpose, six hierarchical regression analyses were conducted, with school climate dimensions as criterions, and characteristics of teachers (i.e. gender, age, work experience and education level) as predictors in the first step, and characteristics of internal school's learning environment as predictors in the second step.

Secondly, the differences in dimensions of school climate are compared among schools, classified into three categories, namely schools with poor, average and good school's internal learning environment. Schools with poor learning environment are those in the first quartile of results on a certain dimension of work conditions, schools with average learning environment 
are those in the middle $50 \%$ of results on a certain dimension, and schools with good learning environment are those in the highest quartile of results on a particular dimension.

\subsection{The explanation of school climate with school's learning environment and characteristics of teachers and teaching}

The results of hierarchical regression analyses predicting dimensions of school climate from characteristics of teachers and school's learning environment are shown in Table 1. School's learning environment significantly contributes to the prediction of interpersonal relations at work, over and above the contribution of characteristics of teachers and teaching, with the total model explaining $48.5 \%$ of variance of this dimension of school climate. The quality of school climate, pertaining to interpersonal relations at work increases with greater satisfaction with work conditions at the level of school and relations among teachers. When it comes to principal's management style, school's learning environment significantly contributes to the prediction of this dimension of school climate, and the only significant predictor identified in this analysis was related to work conditions at the level of school, which are positively associated with the quality of principal's management style. In prediction of relation towards work and students, based on characteristics of teachers and school's learning environment, characteristics of teachers did

Table 1. Hierarchical regression analyses predicting dimensions of school climate from characteristics of teachers and school's learning environment

\begin{tabular}{|c|c|c|c|c|c|c|c|c|c|c|c|c|}
\hline \multirow[b]{3}{*}{$\begin{array}{l}\text { Steps and } \\
\text { predictors }\end{array}$} & \multicolumn{12}{|c|}{ Dimension of school climate } \\
\hline & \multicolumn{2}{|c|}{$\begin{array}{c}\text { Interpersonal } \\
\text { relations at work }\end{array}$} & \multicolumn{2}{|c|}{$\begin{array}{c}\text { Principal's } \\
\text { management style }\end{array}$} & \multicolumn{2}{|c|}{$\begin{array}{l}\text { Relation towards } \\
\text { work and students }\end{array}$} & \multicolumn{2}{|c|}{ Control } & \multicolumn{2}{|c|}{$\begin{array}{c}\text { Interpersonal } \\
\text { relations outside } \\
\text { work }\end{array}$} & \multicolumn{2}{|c|}{ Work overload } \\
\hline & $\Delta R^{2}$ & $\beta$ & $\Delta R^{2}$ & $\beta$ & $\Delta R^{2}$ & $\beta$ & $\Delta R^{2}$ & $\beta$ & $\Delta R^{2}$ & $\beta$ & $\Delta R^{2}$ & $\beta$ \\
\hline Step 1 & .006 & & .002 & & .004 & & .005 & & .006 & & $.019^{*}$ & \\
\hline $\begin{array}{l}\text { Gender - } \\
\text { female }\end{array}$ & & -0.03 & & 0.01 & & -0.05 & & 0.01 & & -0.01 & & $0.09 *$ \\
\hline Age & & 0.04 & & 0.01 & & -0.12 & & -0.02 & & 0.06 & & 0.02 \\
\hline $\begin{array}{l}\text { University or } \\
\text { higher } \\
\text { education }\end{array}$ & & -0.03 & & 0.00 & & 0.02 & & -0.07 & & 0.03 & & -0.05 \\
\hline $\begin{array}{l}\text { Work } \\
\text { experience }\end{array}$ & & -0.03 & & -0.05 & & 0.11 & & -0.04 & & -0.13 & & 0.03 \\
\hline Step 2 & $.479 * * *$ & & $.444 * * *$ & & $.297 * * *$ & & $.080 * * *$ & & $.284 * * *$ & & $.083 * * *$ & \\
\hline $\begin{array}{l}\text { Work } \\
\text { conditions at } \\
\text { school level }\end{array}$ & & $0.22 * * *$ & & $0.58 * * *$ & & $0.45 * * *$ & & $0.28 * * *$ & & $0.14 * *$ & & $0.12 *$ \\
\hline \begin{tabular}{l|} 
Relations \\
among \\
students
\end{tabular} & & 0.04 & & 0.05 & & -0.06 & & 0.02 & & 0.03 & & $0.17 * *$ \\
\hline $\begin{array}{l}\text { Relations } \\
\text { among } \\
\text { teachers }\end{array}$ & & $0.51^{* * *}$ & & 0.08 & & $0.18 * * *$ & & -0.01 & & $0.41 * * *$ & & 0.04 \\
\hline Total $R^{2}$ & $.485^{* * * *}$ & & $.445^{* * *}$ & & $.301 * * *$ & & $.085 * * *$ & & $.290 * * *$ & & $.102 * * *$ & \\
\hline $\mathrm{N}$ & 559 & & 557 & & 563 & & \begin{tabular}{|l|}
558 \\
\end{tabular} & & \begin{tabular}{l|}
559 \\
\end{tabular} & & \begin{tabular}{l|l}
563 \\
\end{tabular} & \\
\hline
\end{tabular}

$*_{p}<.05 . * * p<.01 . * * * p<.001$. 
not contribute significantly to explaining this dimension of organizational climate. School's learning environment explained $30.1 \%$ of variance, over and above characteristics of teachers. Satisfaction with work conditions at the level of school and with relations among teachers are positively related to better relation towards work and students.

In case of prediction of principal's control, the overall variance of this dimension of school climate explained by the used predictors is smaller than that in previous analyses, namely $8.5 \%$, but it is significant. The only significant predictor of greater control is related to more favorable work conditions at the level of school. When it comes to prediction of interpersonal relations outside work, the overall model explains $29.0 \%$ of variance on this dimension of school climate, but characteristics of teachers do not contribute significantly to this prediction. Variables that significantly positively contribute to the prediction of interpersonal relations outside work are work conditions at the level of school and relations among teachers. Work overload was the only dimension of school climate with significant contribution of characteristics of teachers to its explanation. Specifically, teacher's gender is a significant predictor, with female teachers perceiving less work overload than their male colleagues. Better work conditions at the level of school and better relations between students predicted lower work overload.

\subsection{Differences in school climate among schools with poor, moderate and good school's learning environment}

Differences among schools with poor, moderate and good work conditions on all three dimensions of internal school's learning environment in dimensions of school climate are examined and the results of these comparisons are shown in Table 2. Significant differences on all dimensions of school climate were found among schools with poor, average and good work conditions at the level of school, relations between students and relations among teachers. When it comes to conditions at the level of school, Games-Howell post hoc test showed that the perceived school climate on all dimensions is the best in schools with good work conditions, followed by schools with average and poor work conditions ( $\mathrm{p}$ $<.05)$. The only dimension of school climate, on which schools with poor and average conditions at the level of school did not differ, was work overload, but this dimension was rated less positive (i.e., greater work overload) in both groups compared to schools with good work conditions.

Next, Games-Howell post hoc test revealed that school climate is the best in schools with good relations among students, followed by schools with average and poor relations among students on dimensions of interpersonal relations at work, principal's management style, relationship towards work and students, interpersonal relations outside work and work overload. The perceived control was significantly higher in schools with good, compared to schools with poor and average relations among students, while groups with poor and average relations among students did not significantly differ.

Finally, post hoc tests (Games-Howell) showed that there were significant differences among all three groups of schools with different relations among teachers with respect to all dimensions of school climate. School climate is the best in schools with good relations among teachers, followed by those with average relations, and the 
worse in schools with poor relations among teachers.

Significant differences on all dimensions of school climate were found among schools with poor, average and good work conditions at the level of school, relations between students and relations among teachers (Table 2). Games-Howell post hoc test showed that the perceived school climate on all dimensions is the best in schools with good work conditions, followed by schools with average and poor work conditions $(p<.05)$. Next, GamesHowell post hoc test revealed that school

Table 2. Means, standard deviations and analysis of variance examining the differences between schools with poor, moderate and good school's learning environment on the dimensions of school climate

\begin{tabular}{|c|c|c|c|c|c|c|c|c|c|}
\hline & \multicolumn{6}{|c|}{ School's learning environment } & \multirow[b]{3}{*}{$F$} & \multirow[b]{3}{*}{$\eta^{2}$} & \multirow[b]{3}{*}{ Post hoc } \\
\hline & \multicolumn{2}{|c|}{ Poor (1) } & \multicolumn{2}{|c|}{ Average (2) } & \multicolumn{2}{|c|}{ Good (3) } & & & \\
\hline & $M$ & $S D$ & $M$ & $S D$ & $M$ & $S D$ & & & \\
\hline \multicolumn{10}{|c|}{ Conditions at the level of school } \\
\hline Interpersonal relations at work ${ }^{\mathrm{a}}$ & 3.00 & 0.52 & 3.48 & 0.42 & 3.72 & 0.32 & $140.78 *$ & .269 & $1<2<3$ \\
\hline Principal's management style ${ }^{a}$ & 2.79 & 0.57 & 3.32 & 0.48 & 3.74 & 0.31 & $186.56^{*}$ & .328 & $1<2<3$ \\
\hline Relation towards work and students ${ }^{\mathrm{b}}$ & 2.58 & 0.45 & 2.95 & 0.42 & 3.33 & 0.39 & $143.55^{*}$ & .271 & $1<2<3$ \\
\hline Control $^{\mathrm{a}}$ & 2.55 & 0.63 & 2.73 & 0.61 & 3.05 & 0.56 & $31.51^{*}$ & .076 & $1<2<3$ \\
\hline Interpersonal relations outside work ${ }^{\mathrm{c}}$ & 2.21 & 0.50 & 2.53 & 0.56 & 2.92 & 0.55 & $78.52 *$ & .170 & $1<2<3$ \\
\hline Work overload ${ }^{\mathrm{d}}$ & 2.19 & 0.64 & 2.33 & 0.62 & 2.55 & 0.66 & $14.98^{*}$ & .037 & $1,2<3$ \\
\hline \multicolumn{10}{|c|}{ Relations among students } \\
\hline Interpersonal relations at work ${ }^{\mathrm{e}}$ & 3.16 & 0.51 & 3.40 & 0.48 & 3.66 & 0.40 & $58.56^{*}$ & .132 & $1<2<3$ \\
\hline Principal's management style ${ }^{\mathrm{e}}$ & 3.02 & 0.61 & 3.24 & 0.55 & 3.56 & 0.47 & $52.53 *$ & .120 & $1<2<3$ \\
\hline Relation towards work and students ${ }^{\mathrm{f}}$ & 2.79 & 0.48 & 2.90 & 0.49 & 3.14 & 0.46 & $28.67^{*}$ & .069 & $1<2<3$ \\
\hline Control $^{\mathrm{e}}$ & 2.64 & 0.64 & 2.68 & 0.60 & 2.98 & 0.62 & $19.12^{*}$ & .047 & $1,2<3$ \\
\hline Interpersonal relations outside work ${ }^{\mathrm{d}}$ & 2.31 & 0.52 & 2.49 & 0.59 & 2.81 & 0.58 & $41.46^{*}$ & .097 & $1<2<3$ \\
\hline Work overload ${ }^{\mathrm{f}}$ & 2.12 & 0.61 & 2.34 & 0.59 & 2.57 & 0.69 & $26.79^{*}$ & .065 & $1<2<3$ \\
\hline \multicolumn{10}{|c|}{ Relations among teachers } \\
\hline Interpersonal relations at work ${ }^{g}$ & 2.96 & 0.50 & 3.50 & 0.39 & 3.82 & 0.23 & $211.37^{*}$ & .355 & $1<2<3$ \\
\hline Principal's management style ${ }^{g}$ & 2.89 & 0.61 & 3.33 & 0.51 & 3.64 & 0.39 & $92.78^{*}$ & .194 & $1<2<3$ \\
\hline Relation towards work and students ${ }^{\mathrm{f}}$ & 2.65 & 0.48 & 2.96 & 0.44 & 3.31 & 0.39 & $91.43^{*}$ & .191 & $1<2<3$ \\
\hline Controlg $^{g}$ & 2.57 & 0.64 & 2.77 & 0.59 & 2.97 & 0.67 & $17.69^{*}$ & .044 & $1<2<3$ \\
\hline Interpersonal relations outside work ${ }^{\mathrm{h}}$ & 2.15 & 0.47 & 2.59 & 0.55 & 2.96 & 0.54 & $103.46^{*}$ & .212 & $1<2<3$ \\
\hline Work overload $^{\mathrm{f}}$ & 2.15 & 0.63 & 2.37 & 0.60 & 2.53 & 0.70 & $16.98 *$ & .042 & $1<2<3$ \\
\hline
\end{tabular}

Note. The numbers in parentheses in column heads refer to the numbers used for illustrating significant differences $(\mathrm{p}<.05)$ in the "Post hoc" column.

${ }^{a} d f=2,765 .{ }^{b} d f=2,773 .{ }^{c} d f=2,768 .{ }^{d} d f=2,772 .{ }^{e} d f=2,770 .{ }^{f} d f=2,778 .{ }^{f} d f=2,777$.

${ }^{g} d f=2,769 .{ }^{h} d f=2,771$.

$*_{p}<.001$. 
climate is the best in schools with good relations among students, followed by schools with average and poor relations among students on dimensions of interpersonal relations at work, principal's management style, relations towards work and students, interpersonal relations outside work and work overload. The perceived control was significantly higher in schools with good, in comparison to schools with poor and average relations among students $(p<.05)$. Finally, post hoc tests (GamesHowell) show that school climate is the best in schools with good relations among teachers, followed by those with average and poor relations among teachers with respect to interpersonal relations at work, principal's management style, relation towards work and students, interpersonal relations outside work and control, while in the case of work overload, schools with poor relations among teachers rated this dimension of school climate significantly more negative than those with average and poor relations $(p<.05)$.

\section{DISCUSSION}

The outcomes of all performed analyses point to the conclusion that school climate is a characteristic that has a strong potential for discriminating schools, based on the quality of their functioning. Schools, where teachers perceived the learning environment to be poor, average or good, clearly differ in their quality of school climate. Specifically, in all of the analyses school climate is significantly better in schools with better learning environment.

The findings of this study present a valuable contribution to the existing body of knowledge on the quality of school climate by empirically supporting a number of expectations, described in different theoretical models of school climate. Phelan, Davidson and $\mathrm{Yu}$ (1996) conclude that in order to develop schools with "students at the center", it is necessary that school internal and especially learning context, as important determinants of learning environment, are at a satisfactory level. These two contexts within school have a direct effect on student school achievement, but they also have an indirect effect, by creating a positive school climate. In the present study, schools with poorer learning environment, i.e. with more poorly educated and less motivated teachers, lower sense of student belonging to school, surrounding that does not motivate students or teachers to achieve more, are also schools with poorer school climate. Consequently, these schools have poorer school and student outcomes. Higgins-D'Alessandro and Sakwarawid (2011, according to Thapa et al., 2013) showed that students with disabilities can profit from school only if they feel included, accepted and respected by other students and teachers. Similar conclusion can be applied to all students, irrespective of their status and possible difficulties or disabilities.

Based on the outcomes of the study regarding the relation between school's learning environment and school climate, it is possible to reinterpret, to a certain degree, older educational studies, primarily focused on the role of material conditions, in explaining school and students' achievement. These studies showed that material conditions are necessary to ensure school effectiveness. On the other hand, some researchers have tried to dispute these findings. It is possible, as well as expected, that an indirect relation exists between material conditions and school achievement, through school climate (Brookover, Schweitzer, Schneider, Beady, Flood, \& Wisenbaker, 1978). The effects of student and family characteristics, which were a dominant 
theme in studies during 1970s, and their influence on school effectiveness, can be considered in the similar way.

When considered together, the material conditions, characteristics of students, parents and teachers, and as demonstrated in this study, characteristics of schools, such as school climate, clearly point to the necessity of conceptualizing schools as "dynamic systems that influence a broad range of dimensions of student learning, including affective, social, behavioral as well as academic domains" (Deakin Crick, et al., 2013).

The second important outcome of this study is related to the possibility of predicting school climate and its dimensions, based on characteristics of teachers and latent dimensions which determine the quality of school's internal learning environment. The results of the hierarchical regression analyses provide a detailed insight into the possible mechanisms of how a positive school climate could be created and maintained. The features of work conditions at school have been shown to be the most important determinant of school climate, while the relations among students and relations among teachers are generally less important, i.e. important only for some conceptually similar aspects of school climate, such as interpersonal relations in school and relation towards work and students.

The findings that stress the importance of work conditions at school, as an important aspect of the quality of school learning environment, need to be considered within a particular context. In the Croatian educational system, significant differences in student achievement exist, depending on the urbanization level of school's surrounding, material conditions and other determinants of school achievement, primarily related to material resources (Burušić, Babarović, Šakić, 2009; Burušić, Babarović, Šakić \&
Dević, 2013). These findings can contribute to the existing body of knowledge in the educational studies, since they are obtained in an educational system that significantly differs from those in developed countries, with respect to equality of schools in available material resources, and in addition, where huge intragroup variabilities among schools working conditions exist.

The outcome of this study that the dimension of school climate, pertaining to relations towards work and students, can be predicted, based on characteristics of the learning environment, related to direct interpersonal relations among students is interesting and provides a conceptual confirmation of the performed analyses. Namely, according to the results of this study, teachers' approach depends on the behavior and interactions of students. In other words, although it can be expected that teachers (ideally) have a universal approach to teaching and universal standards of quality in their work, this finding empirically confirms that teachers adapt their approach to processes within classrooms and schools. In the existing models of school effectiveness, the variability in teachers' behavior, which is not a result of the need to achieve the same educational goals through different and available ways, is often ignored. This certainly presents an important area for future studies.

The results of this study should be considered taking into account the employed research design. Possible future improvements of the research design used in this study can be based on the suggestions by Thapa et al. (2013). Namely, the relations between school's learning environment and perceived school climate should be examined longitudinally, since such a design would enable a clearer representation of the strength and dynamics of relations between these constructs. 
Hierarchically structured relations among behavior of students and teachers and processes in the school setting should also be taken into account. A combination of quantitative and qualitative approach, using mixedmethod models, would also present a significant improvement of the research design and provide valuable information for a more detailed understanding of the dynamics of relations pertaining to school climate, as well as an explanation of certain mediating processes that is clearer and closer to school reality.

Studies based on such complex research designs could improve knowledge gained by using cross-sectional designs. They should stress the importance of ecology within schools, where the paramount goal is to create internal school conditions, in which teachers, students and parents experience school as a place of positive feelings. The outcomes of this study confirm the expectation that the analysis of school achievement must acknowledge the processes related to organizational climate. They represent an important aspect,

\section{References}

1. Anderson, C. S. (1982). The search for school climate: A review of the research. Review of educational research, 52(3), 368-420.

2. Bascia, N. (2014). The School Context Model: How School Environments Shape Students' Opportunities to Learn. In Measuring What Matters, People for Education. Toronto: November 8, 2014

3. Benbenisty, R. \& Astor, R.A. (2005). School violence in context: Culture, neighborhood, family, school, and gender. New York: Oxford University Press.

4. Berkowitz, R., Moore, H., Astor, R. A., \& Benbenishty, R. (2017). A research interacting with numerous individual factors, extensively examined in many educational studies.

\section{CONCLUSION}

Schools, in which teachers perceive the school's learning environment as a good one, clearly differ in the level of school climate quality - school climate is significantly better in schools with better school's learning environment. The performed hierarchical regression analyses demonstrated that school's learning environment and characteristics of teachers and teaching practice (e.g. gender, age, work experience and education level) are powerful predictors of school climate. The outcome of the study suggests how educational system can potentially improve overall effectiveness, stressing an importance of the issues related to positive school climate. Schools can potentially enhance student achievement and learning outcomes by improving their learning environments.

synthesis of the associations between socioeconomic background, inequality, school climate, and academic achievement. Review of Educational Research, 87(2), 425-469.

5. Brookover, W. B., Schweitzer, J. H., Schneider, J. M., Beady, C. H., Flood, P. K., \& Wisenbaker, J. M. (1978). Elementary school social climate and school achievement. American Educational Research Journal, 15(2), 301-318.

6. Bryk, A., \& Schneider, B. (2002). Trust in schools: A core resource for improvement. Russell Sage Foundation.

7. Buening, J. G. (2014). Non-Academic Differences Between Public and 
Private High Schools: The Importance of School Climate (Doctoral dissertation, Miami University).

8. Burušić, J., Babarović, T., \& Šakić, M. (2009). Odrednice uspješnosti osnovnih škola u Republici Hrvatskoj: rezultati empirijske provjere. Društvena istraživanja: časopis za opća društvena pitanja, 18(4-5 (102-103)), 605-624.

9. Burušić, J., Šakić, M., Babarović, T., \& Dević, I. (2013). School achievement in urban and rural areas in Croatia: Is the quality of education equal for all? In B. Boufoy-Bastick (Ed.), Cultures of educational policy: Comparative international issues in policy-outcome relationships (pp. 187-217). Strasbourg, France: Analytrics.

10. Cheema, J. R., \& Kitsantas, A. (2014). Influences of disciplinary classroom climate on high school student self-efficacy and mathematics achievement: A look at gender and racial-ethnic differences. International Journal of Science and Mathematics Education, 12(5), 1261-1279.

11. Cohen, J. \& Geier, V.K. (2010). School Climate Research Summary: January 2010. New York, N.Y. (www.schoolclimate.org/climate/ research.php).

12. Cohen, J., McCabe, L., Michelli, N. M., \& Pickeral, T. (2009). School climate: Research, policy, practice, and teacher education. Teachers college record, 111(1), 180-213.

13. Coleman, J., Campbell, E.,Hobson, C.,McPartland, J.,Mood, A.,Weinfield, F., York, R. (1966.). Equality of educational opportunity, Washington, DC, U.S. Department of Health, Education, and Welfare, Office of Education.

14. Creemers, B. P., \& Kyriakides, L. (2006). Critical analysis of the current approaches to modelling educational effectiveness: The importance of establishing a dynamic model. School Effectiveness and School Improvement, 17(3), 347-366.

15. Deakin Crick, R., Haigney, D., Huang, S., Coburn, T. and Goldspink, C. (2013) Learning power in the workplace: the effective lifelong learning inventory and its reliability and validity and implications for learning and development, The International Journal of Human Resource Management, 24 (11), 2255-2272.

16. Domović, V. (2003). Školsko ozračje $i$ učinkovitost škole. Jastrebarsko: Naklada Slap.

17. Dronkers J, Robert P (2003) The effectiveness of public and private schools from a comparative perspective. EUI Working Paper SPS 2003-13. European University Institute, Florence.

18. Halpin, A., \& Croft, D. (1963). The organizational climate and individual value systems upon job satisfaction. Personnel Psychology, 22, 171-183.

19. Hanushek, E. A. (1986). The economics of schooling: Production and efficiency in public schools. Journal of Economic Literature, 24(3), 1141-1177.

20. Hedges, L. V., Laine, R. D., \& Greenwald, R. (1994). An exchange: Part I: Does money matter? A metaanalysis of studies of the effects of differential school inputs on student outcomes. Educational Researcher, 23(3), 5-14.

21. Higgins-D'Alessandro, A., \& Sakwarawich, A. (2011, October). Congruency and determinants of teacher and student views of school culture. Paper presented at the Association for Moral Education annual conference, Nanjing, China. 
22. Hoy, W. K., \& Clover, S. I. (1986). Elementary school climate: A revision of the OCDQ. Educational Administration Quarterly, 22(1), 93-110.

23. Johnson, B., \& Stevens, J. J. (2006). Student achievement and elementary teachers' perceptions of school climate. Learning Environments Research, 9(2), 111-122.

24. Kottkamp, R. B., Mulhern, J. A., \& Hoy, W. K. (1987). Secondary school climate: A revision of the OCDQ. Educational Administration Quarterly, 23(3), 31-48.

25. National School Climate Council (2007). National school climate standards. http://www.schoolclimate.org/ climate/documents/school-climatestandards-csee.pdf

26. Phelan, P., A. Davidson \& $\mathrm{H}$. Yu (1996). Adolescents' worlds: Negotiating family, peers and school. New York: Teachers College Press.

27. Proroković, A., Slišković, A. (2008). Upitnik organizacijske klime za srednje škole. Zbirka psihologijskih skala $i$ upitnika. Sv.4. ur. Penezić, Z.; ĆubelaAdorić, V.; Proroković, A.; Ivana Tucak Junaković: Sveučilište u Zadru, Zadar.

28. Scheerens, J. (1989). Processindicators of school functioning: A selection based on the research literature on school effectiveness. Paper for the OECD Educational Indicator Project, Semmering, Austria, 18-22 September 1989.

29. Thapa, A., Cohen, J., Guffey, S., \& Higgins-D’Alessandro, A. (2013). A review of school climate research. Review of Educational Research, 83(3), 357-385.

30. Townsend, T. (2007) (eds). International Handbook of School Effectiveness and Improvement. Springer International Handbooks of Education. Dordrecht: Springer.

31. Van Houtte, M. (2005). Climate or culture? A plea for conceptual clarity in school effectiveness research. School effectiveness and school improvement, 16(1), 71-89.

32. Wang, M. T., \& Degol, J. L. (2016). School climate: A review of the construct, measurement, and impact on student outcomes. Educational Psychology Review, 28(2), 315-352.

33. Yonezawa, S., Jones. M., Mehan, H., \& McClure, L. (2008). School climate and student achievement. In $\mathrm{T}$. Timar and J. Maxwell-Jolly (Eds). Connecting the dots and closing the gap. Chapter wrote for the California Superintendent of Public Schools P-16 Council. Davis, CA: Center for Applied Policy in Education, UC Davis. 


\section{PERCIPIRANO ŠKOLSKO OZRAČJE U HRVATSKIM OSNOVNIM ŠKOLAMA S LOŠIM, PROSJEČNIM I DOBRIM ŠKOLSKIM OKRUŽENJEM ZA UČENJE}

\section{Sažetak}

U ovom se radu koristi kros-sekcijski istraživački nacrt za istraživanje razlika u nastavničkoj percepciji školskog ozračja u školama s lošim, prosječnim i dobrim školskim okruženjem za učenje, kao i za utvrđivanje razina u kojoj je moguće objasniti šest dimenzija školskog ozračja pomoću školskog okruženja za učenje, obilježja nastavnika i njihove prakse u nastavi. U studiji je sudjelovalo 785 nastavnika/ica iz 44 osnovne škole u sjevernom dijelu Hrvatske, od čega 121 nastavnik i 579 nastavnica. Sudionici su ocjenjivali školsko ozračje u svojoj školi, kao i školsko okruženje za učenje. Škole, u kojima nastavnici/e okruženje za učenje percipiraju kao dobro, jasno se razlikuju s obzirom na kvalitetu školskog ozračja, pri čemu je ozračje mnogo bolje u školama s boljim okruženjem za učenje. U radu se koristi hijerarhijska regresijska analiza, koja pokazuje da su školsko okruženje za učenje, kao i obilježja nastavnika $i$ njihove nastavne prakse (npr. spol, dob, radno iskustvo i razina obrazovanja) snažni prediktori pozitivnog školskog ozračja. Pružaju se moguća objašnjenja navedenih rezultata i naglašava značaj školskog ozračja kao koncepta, ključnog za pojam i aktivnosti, vezane uz školsku efektivnost.

Ključne riječi: školsko ozračje, školsko okruženje za učenje, osnovne škole, školska efektivnost 